\title{
Model Studies Related to Vanadium Biochemistry: Recent Advances and Perspectives
}

\author{
Enrique J. Baran \\ Centro de Química Inorgánica (CEQUINOR/CONICET,UNLP), Facultad de Ciencias Exactas, \\ Universidad Nacional de La Plata, C. Correo 962, 1900-La Plata, Argentina
}

\begin{abstract}
Nos ultimos anos, vêm se acumulando as evidências sobre a necessidade de vanádio dos organismos mais evoluídos. Estudos de compostos modelos constituem-se numa importante ferramenta para o entendimento dos diferentes aspectos da bioquímica deste bioelemento. Neste artigo, apresentamos os resultados dos nossos estudos, assim como os de outros grupos de pesquisa, sobre compostos modelos relacionados a vários aspectos do metabolismo e detoxificação do vanádio e a haloperoxidasas dependentes do vanádio. São também apresentadas informações sobre as interações do cátion oxovanádio(IV), relevante do ponto de vista biológico, com bioligantes importantes, tais como nucleotideos, carboidratos, fosfatos e outros sistemas correlatos.
\end{abstract}

Increasing evidence on the need of the higher forms of life for vanadium has accumulated during recent years. Model studies have become a very important tool to attain a better understanding of different aspects of the biochemistry of this bioelement. In this account we present the results of our own studies, as well as those of other research groups, on models related to different aspects of its metabolism and detoxification and to vanadium dependent haloperoxidases. Additional information about the interaction of the biologically relevant oxovanadium(IV) cation with important bioligands, such as nucleotides, carbohydrates, phosphates and related systems are also presented.

Keywords: vanadium, model studies, metabolism, detoxification, haloperoxidases, biologically relevant ligands

\section{Introduction}

The biological effects, biodistribution and toxicology of vanadium, such as its requirement and pharmacological activity, are areas of increasing research interest. Although numerous biochemical and physiological functions have been suggested for this element, and despite the amount of the knowledge so far accumulated, vanadium still does not have a clearly defined role in the higher forms of life..$^{1-5}$

The best evidence for a biological role of vanadium comes from bacteria (the so-called alternative nitrogenases in which vanadium replaces molybdenum in the FeMocofactor of some Azotobacter species) $)^{4-7}$ and from plants (vanadium- dependent haloperoxidases found in some algae, lichens and fungi). ${ }^{4,5,8,9}$

On the other hand, experiments with laboratory animals have shown that vanadium deprivation enhances abortion rates, reduces milk levels during lactation and produces thyroidal disorders. Other evidence points to the possible role of vanadium in the regulation of ATP-ases, phosphoryl

\footnotetext{
* e-mail: baran@quimica.unlp.edu.ar
}

transfer enzymes, adenylate cyclase, and protein kinases. However, many actions of vanadium can be also explained by its having a role similar to, or enhancing recently described growth factors such as the epidermal growth factor, the fibroblast growth factor and even insuline. ${ }^{10}$

Like molybdenum, vanadium occupies an exceptional position among the bioelements because both, anionic and cationic forms can participate in biological processes. ${ }^{3,5,11,12}$ In its anionic forms (vanadates $(\mathrm{V})$ ), it resembles phosphates, but in its cationic forms - mainly as $\mathrm{VO}^{2+}$ - it behaves like a typical transition metal ion, which competes with other metal cations in coordination with biogenic ligands or compounds. This duality, together with the facility with which it changes oxidation states and coordination environments, may be responsible for the very peculiar and somewhat unparalleled behavior of this biometal. ${ }^{5,12}$

Aspects of the coordination chemistry of vanadium relevant to its presence and activity in biological systems have been recently reviewed. ${ }^{2-4,11-14}$ In this account we will present some of our recent results of studies on model systems related to aspects of the biochemistry of vanadium and those of other research groups working in this field. 


\section{Model Studies Related to Vanadium Metabolism}

Although information about the metabolism of physiological amounts of vanadium in the higher forms of life remains scarce, an increasing amount of data has accumulated during recent years, mainly from animal studies. Some general aspects related to the absorption, transport, biological transformations, toxicity and excretion of vanadium become understandable. ${ }^{15,16}$

In Figure 1 we present a summary of this knowledge, briefly summarized, as follows: Dietary vanadium occurs mainly as $\mathrm{H}_{2} \mathrm{VO}_{4}^{-}$and enters cells probably through the phosphate transport mechanism. Most of the ingested vanadium $(V)$ undergoes a rapid one-electron reduction in the gastrointestinal tract, consistent with the fact that vanadium $(\mathrm{V})$ is a rather strong oxidizing agent, especially at low $\mathrm{pH}$. Most of the ingested and reduced vanadium remains unabsorbed and is excreted. Strong association between $\mathrm{VO}^{2+}$ and dietary fiber is postulated. In vivo, all the vanadium is converted to a common form. The organ distribution is essentially independent of the oxidation state and chemical nature of the form of the element. Evidently $\mathrm{VO}^{2+}$ undergoes autooxidation to vanadate in the presence of oxygen, whereas glutathione, ascorbate, cysteine and similar reducing agents can reduce vanadate. This means that endogenous reducing agents and dissolved oxygen ensure that both vanadium(V) and vanadium(IV) species are present in serum. Experimental evidence points to a relation between vanadium and iron metabolism. It has been suggested that the iron- transport protein transferrin may be also involved in vanadium transport. It remains to be determined if ferritin, the storage protein for iron, is also a useful storage system for vanadium. Interactions between vanadium species and serum albumin are probable, but very little is known about these processes and the possible nature of the complexes generated. Bone seems to be the major sink for vanadium. Final excretion of the small fraction of ingested and not retained vanadium occurs mainly through urine, as low-molecular-weight $\mathrm{VO}^{2+}$ complexes. Biliar excretion seems to be a secondary route.

We have performed a series of model studies related to different steps of the metabolic patterns in order to clarify some essential aspects.

\subsection{Complexes of glutathione and related ligands}

Reduced glutathione (GSH, Figure 2a), the tripeptide $\gamma$-L-glutamyl-L-cysteinylglycine, the major non-protein thiol present in animal cells, is an extremely important biological reducing agent, involved in detoxification processes of exogenous materials ${ }^{17}$ and apparently plays a central role in vanadium metabolism.

Besides its reducing potential GSH can act as a ligand for the stabilization of the $\mathrm{VO}^{2+}$ oxocation. ${ }^{12,18,19}$ Consequently, we have repeatedly investigated the $\mathrm{VO}^{2+} / \mathrm{GSH}$ system. Our first studies, using electronic absorption spectroscopy, have shown that the interaction is strongly dependent on the initial metal-to-ligand ratios and the $\mathrm{pH}$ of the solution, and at least two different species were identified. ${ }^{20}$ More detailed speciation studies of this system have shown an even higher complexity. ${ }^{21,22}$ In the most recent and complete study, combining $\mathrm{pH}$-potentiometry with EPR spectroscopy, visible absorption and circular dichroism measurements, it was shown that in the $\mathrm{pH}$ range between 5 and 7.5 and at any ligand-to-metal ratio between

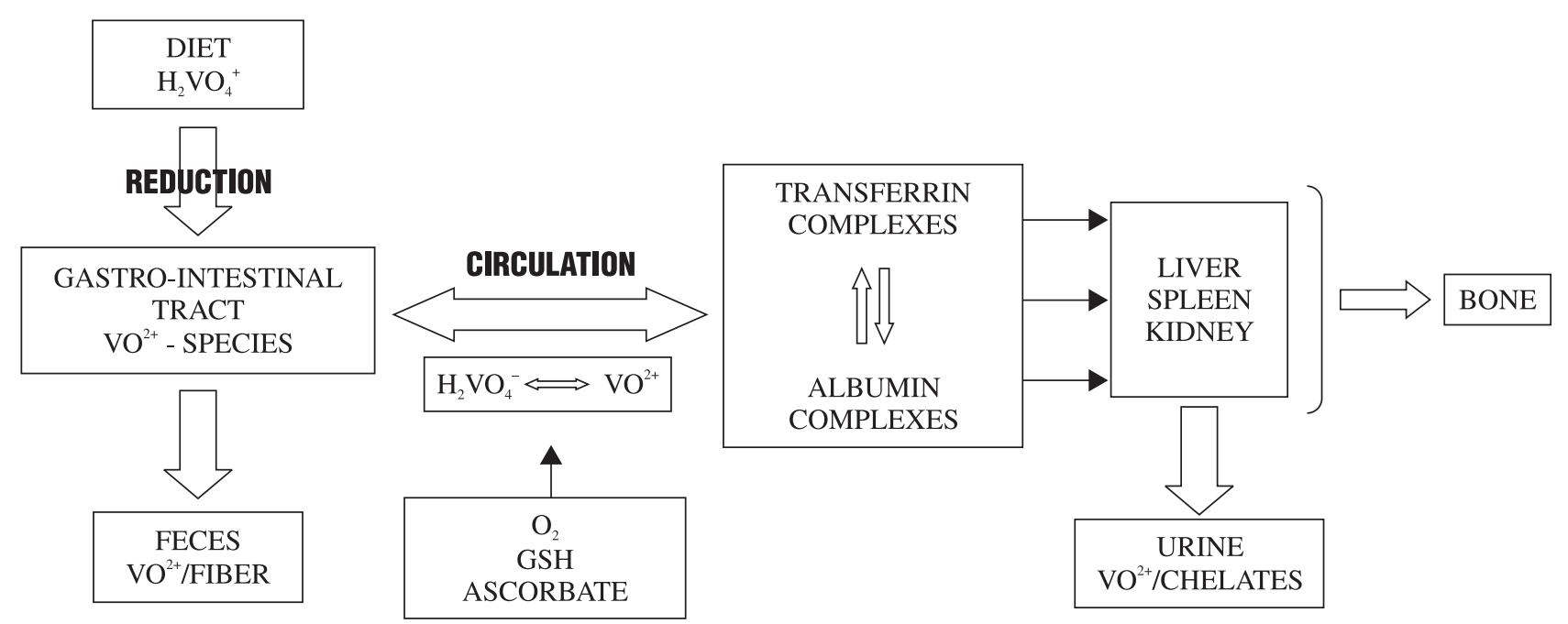

Figure 1. Schematic representation of vanadium metabolism in higher forms of life. 
10 and 140, the predominant complex, is a 2:1 species in which each GSH molecule coordinates through one Oatom of the deprotonated carboxylate group and the amino $\mathrm{N}$-atom of the glutamyl residue. ${ }^{22}$ Four other species were identified in other $\mathrm{pH}$-ranges. ${ }^{22}$ Previous EPR studies of this system also support $\mathrm{VO}^{2+}$ interaction through oxygens of the deprotonated carboxylate groups, and $\mathrm{NH}_{2}$ moieties. $^{23}$

On the other hand, a series of model compounds with sulfhydryl-containing pseudopeptides, and investigated by a combination of numerous physicochemical techniques, also demonstrates the predominance of the cited 2:1 species in the $\mathrm{pH}$ range 5-7. ${ }^{24}$

The oxidation product of glutathione (GSSG, Figure 2b) can also interact with the $\mathrm{VO}^{2+}$ cation, and model speciation calculations reveal that in the $\mathrm{pH}$ range 6-7, GSSG is a more efficient oxovanadium(IV) binder than GSH. ${ }^{22}$ Two different 2:1 complexes, easily interconverted simply by changing the metal-to-ligand concentrations, are generated in the GSSG/VO ${ }^{2+}$ system. At low GSSG concentrations, coordination takes place through carboxylate groups, whereas at higher concentrations, $\mathrm{N}$-donors appear to be principally involved in coordination. ${ }^{25}$ EPR studies at a $25: 1$ ligand-to-metal ratio suggest coordination through one or two monodentate carboxylate groups or through one or two $\alpha$-amino acid moieties, i.e., $\mathrm{COO}^{-}+\mathrm{NH}_{2}$ or $2 \mathrm{COO}^{-}+2 \mathrm{NH}_{2} \cdot{ }^{23}$

Most recently, Costa Pessoa et al. ${ }^{26}$ performed a detailed speciation study of this system. They concluded that in the $\mathrm{pH}$ range 6-8 and at a ligand-to-metal ratio $=10$, a 1:1 species predominates. Coordination in this complex involves one carboxylate oxygen-atom and the $\mathrm{NH}_{2}$ group of the two terminal glutamyl moieties of GSSG.

These results confirm that both GSH and GSSG may participate in the stabilization and in the transport of $\mathrm{VO}^{2+}$ immediately after the GSH-mediated reduction of vanadate $(\mathrm{V})$ in cellular systems. ${ }^{16,22}$

The amino acid L-cysteine is another potential reducing agent for vanadate in biological systems. Model studies in the $\mathrm{VO}_{3}^{-}$-cysteine system show that vanadate is rapidly reduced, irrespective of the $\mathrm{pH}$ of the solution. At $\mathrm{pH} 6.8$, reduction is followed by the formation of a purple complex. In this 2:1 ligand-to-metal species, the $\mathrm{VO}^{2+}$ cation interacts with the amino $\mathrm{N}$-atom and the deprotonated - SH group of two amino acid molecules. ${ }^{27}$ This complex seems to be similar to the $\mathrm{VO}^{2+}$ complexes of cysteine esters of the same stoichiometry, which were isolated in the solid state. ${ }^{28,29}$ We also demonstrated that oxovanadium(IV) interacts with cystine, the oxidation product of L-cysteine. In this case, coordination apparently occurs through the carboxylate and amino groups. ${ }^{30}$ These results suggest that again both the excess of amino acid or its oxidation product was bind to the $\mathrm{VO}^{2+}$ cation.

\subsection{Oxovanadium(IV) complexes of $L$-ascorbic acid and of its oxidation products}

L-ascorbic acid (vitamin C, Figure 3) is another possible natural reducing agent of vanadates( $\mathrm{V})$ to oxovanadium(IV). The reduced species can interact with the acid and with some of its oxidation products. ${ }^{12,31,32}$

A detailed study of the interaction of L-ascorbic acid with the $\mathrm{VO}^{2+}$ cation showed that different complexes are generated in solution at different $\mathrm{pH}$-values. Some of them were isolated as powdered solids. As shown by spectroscopic studies, in these complexes the acid acts as a monodentate ligand through its deprotonated 3-hydroxo group, generating species of very low stability, consistent with the absence of chelation, suggesting that these $\mathrm{VO}^{2+} /$ ascorbate complexes are probably not significant in the stabilization of the reduced vanadium.

On the other hand, the $\mathrm{VO}^{2+}$ cation might interact with some of the species generated after the oxidation of L-ascorbic acid. ${ }^{32}$ Dehydroascorbic acid, which is the primary oxidation product, is very unstable and undergoes a rapid series of transformations, first generating 2,3diketogulonic acid, which can be further degraded to a mixture of oxalic and L-threonic acids. ${ }^{12,16,32}$ Dehydroascorbic acid interacts rapidly with $\mathrm{VO}^{2+}$. Solutions of these adduct are highly unstable towards the oxidation of the ligand. The $\mathrm{VO}^{2+} /$ dehydroascorbate complex hydrolyzes irreversibly with opening of the lactone ring, generating a 2:1 ligand-to-metal complex, in which the enolized form of 2,3-diketogulonic acid is bidentate. A sodium salt of this complex anion, of composition $\mathrm{Na}_{2}\left[\mathrm{VO}\left(\mathrm{C}_{6} \mathrm{H}_{6} \mathrm{O}_{7}\right)_{2}\right] \cdot 3 \mathrm{H}_{2} \mathrm{O}$, has been isolated and characterized. ${ }^{32}$

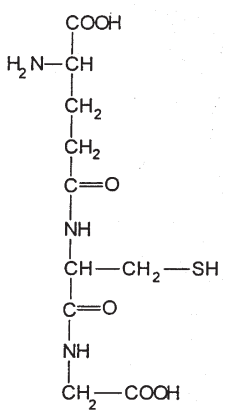

a

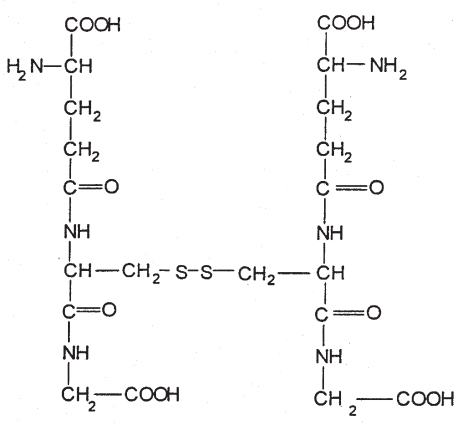

b
Figure 2. Reduced glutathione (a) and oxidized glutathione (b). 


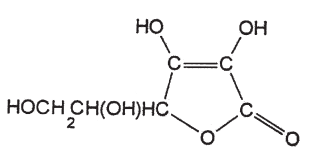

Figure 3. L-ascorbic acid.

Recently, we characterized some other $\mathrm{VO}^{2+}$-complexes of this type, obtained as microcrystalline powders, by direct interaction of sodium metavanadate with ascorbic acid. ${ }^{33}$

\subsection{Transferrin and serum albumin complexes}

It is well known that in the oxidation states $+3,+4$ and +5 , vanadium binds tightly to transferrin ${ }^{3,13,34}$, forming vanadium-modified transferrins, which are believed to be involved in vanadium transport in higher organisms. ${ }^{35}$ Nevertheless, the coordination environment around vanadium in these systems is not yet totally known.

Vanadium $(\mathrm{V})$ interaction with human serum transferrin has been investigated in detail, showing that two equivalents of vanadate are reversibly bound at the two metal-binding sites of the protein. ${ }^{36}$ The interaction was also modeled using the hexadentate ligand ethylenebis(o-hydroxyphenlylglycine) showing that, at $\mathrm{pH} 9.5$, the vanadium is bonded to phenolic residues as the $\mathrm{VO}_{2}^{+}$ cation. ${ }^{36}$

In the case of the $\mathrm{VO}^{2+}$-complex of human lactoferrin, an octahedral structure with $\mathrm{O}_{3} \mathrm{~N}$ equatorial coordination, involving one tyrosinate, one aspartate, one histidine and one monodentate carbonate, with another tyrosinate trans to the $\mathrm{V}=\mathrm{O}$ bond has been proposed, on the basis of a computer simulation, using the atomic coordinates of the $\mathrm{Fe}^{\mathrm{III}}$ and $\mathrm{Cu}^{\mathrm{II}}$ complexes. ${ }^{37}$ Vanadium(III), as $\mathrm{V}^{3+}$, and vanadium(V) as $\mathrm{VO}_{2}{ }^{+}$, can also be accommodated in a similar environment. ${ }^{37}$

Recently, Neves et al. ${ }^{38,39}$ have prepared some interesting model systems for the $\mathrm{VO}^{2+}$-transferrin complex, using N,O-donor ligands. With some of these models they were able to reproduce UV-Vis and EPR properties of oxovanadium(IV) complexes of human serum transferrin and ovotransferrin and they advanced some new proposals about the coordination sphere of vanadium in these systems. It has also been shown that some of these complexes can be oxidized chemically or electrochemically to the respective vanadium $(\mathrm{V})$ complexes without changing the coordination sphere of the vanadium. ${ }^{39}$

Some aspects of the vanadium/albumin interactions are now understood. ${ }^{13,34}$ In one of the first EPR studies of the $\mathrm{VO}^{2+} /$ bovine serum albumin system, it was found that the cation binds tightly probably at the specific sites for
$\mathrm{Cu}^{\mathrm{II}}$, located at the $\mathrm{N}$ terminus of the polypeptide chain. There are also four or five additional weaker binding sites for $\mathrm{VO}^{2+}$ at carboxylate groups of the protein. However, the nature of the metal coordination sites could not be unambiguously established. ${ }^{40}$

The interaction of $\mathrm{VOSO}_{4}$ and $\mathrm{NaVO}_{3}$ with human serum albumin (HSA) was also investigated in aqueous solution at physiological $\mathrm{pH}$, using gel and capillary electrophoresis and IR spectroscopic techniques. Gel electrophoresis results showed that a maximum of twenty $\mathrm{VO}^{2+}$ cations is bound per HSA molecule, at two sites with different affinities. Capillary electrophoresis confirmed the existence of two major binding sites for the oxovanadium(IV) cation, whereas $\mathrm{VO}_{3}^{-}$has only a very weak binding affinity ${ }^{41}$, consistent with previous studies. ${ }^{42}$

IR spectroscopic analysis showed that, as a consequence of the $\mathrm{VO}^{2+} / \mathrm{HAS}$ interaction, major structural changes are produced at the protein secondary structure. ${ }^{41}$

In a recent comparative study of the binding of vanadate to HSA, human fresh frozen plasma and human transferrin, it was demonstrated that the binding capacity of HSA is about one thousandth of those of the other two systems. ${ }^{43}$

\subsection{Accumulation of vanadium in hard tissues and related systems}

Bone seems to be the most active vanadium accumulator. The high skeletal retention of vanadate is probably related to its rapid exchange with bone phosphate, which must be favored by the strong similarities of $\mathrm{PO}_{4}^{3-}$ and $\mathrm{VO}_{4}^{3-}$.

In order to investigate this exchange, calcium hydroxylapatite, $\mathrm{Ca}_{10}\left(\mathrm{PO}_{4}\right)_{6}(\mathrm{OH})_{2}$, was used as a model for the inorganic phase of bone. ${ }^{44}$ Under physiological conditions, the exchange was only observed with amorphous material. These model studies showed that the incorporation of small amount of vanadium into the phosphate sites only produces weak distortions at macroscopic (crystallographic parameters, crystal ordering) and microscopic (local distortions, weakening of chemical bonds) levels in the apatite lattice. ${ }^{44}$

Possible competition between $\mathrm{VO}^{2+}$ and $\mathrm{Ca}^{\mathrm{II}}$ in the hydroxylapatite lattice has also been analyzed. Precipitation of $\mathrm{Ca}_{10}\left(\mathrm{PO}_{4}\right)_{6}(\mathrm{OH})_{2}$ in the presence of oxovanadium(IV) ${ }^{45}$ as well as interaction of apatite suspensions with the oxocation ${ }^{46}$ demonstrated that $\mathrm{VO}^{2+}$ is not incorporated into the apatite lattice, but that it is strongly adsorbed on the material surface. ${ }^{46,47}$

In addition, in vivo experiments, analyzing bone samples of rats treated with an interesting and promising 
antidiabetic drug, ${ }^{48}$ bis(maltolato)oxovanadium (IV), by means of electron spin-echo envelope modulation (ESEEM) spectroscopy, suggest that phosphate is involved in this surface interaction of $\mathrm{VO}^{2+}$ with bone. ${ }^{49}$

As it is known ${ }^{34,50}$ that $\mathrm{VO}^{2+}$ interacts with tropocollagen, it was useful to investigate whether it interacts with components of the organic matrix of bone. The interaction of $\mathrm{VO}^{2+}$ with chondroitin sulfate A (CSA), a well-known muchopolysaccharide present in connective tissues and other mineralized systems, was investigated in aqueous solutions by electron absorption spectroscopy and IR techniques. The generation of a complex species of stoichiometry $\mathrm{VO}(\mathrm{CSA})_{2}$, involving metal coordination to the carboxylate group and the glycosidic oxygen of the D-glucuronate units of CSA was demonstrated. ${ }^{51}$ It was also found that the two isolated components of CSA (Dglucuronic acid and $N$-acetylgalactosamine) behave towards $\mathrm{VO}^{2+}$ in a similar way as they do in the muchopolysaccharide. ${ }^{52}$

\subsection{Vanadium excretion}

As mentioned in the introduction, ingested vanadium is excreted most rapidly fecally. The postulated strong association of $\mathrm{VO}^{2+}$ with dietary fiber must be facilitated by the high affinity of the oxocation for a number of functional residues such as carboxylate, phosphate or hydroxo groups. However, very little information about the characteristics of these interactions in the gastrointestinal tract is available.

Concerning the final urinary excretion of the fraction of vanadium initially retained there exist a number of conflicting reports. Probably this excretion involves lowmolecular-weight $\mathrm{VO}^{2+}$ complexes. ${ }^{15}$ However, other evidence also suggest the simultaneous presence of high molecular-weight complexes. ${ }^{53}$

In recent studies the low-molecular-weight vanadium species in urine was identified as a vanadium/ascorbate complex. ${ }^{54,55}$ But on the basis of our studies with this system, discussed above (section 2.2.), it is most likely that the ligand may be any of the oxidation products of ascorbic acid, perhaps 2,3-diketogulonic acid.

In the most recent study of this system it was shown that, after intraperitoneally ${ }^{48} \mathrm{~V}$ injection, vanadium in urine is found both as high-(protein-bound) and as lowmolecular-weight species. The partition of these forms apparently depends on the time elapsed after vanadium administration. Different high- and low-molecular-weight forms were detected by chromatography depending of the elapsed times. But, after $48 \mathrm{~h}$ vanadium is largely excreted as a low-molecular-weight complex. ${ }^{56}$

\section{Other Models of Biochemical Interest}

A great number of other vanadium-containing complexes and systems are also of direct biochemical interest. In this section we restrict the information only to some aspects of systems involving nucleotides, phosphates and carbohydrates and some closely related ligands.

\subsection{Interaction of $\mathrm{VO}^{2+}$ with nucleotides and related materials}

The coordination behavior of both vanadates(V) and oxovanadium(IV) with nucleotides and their constituents is of great interest in relation to competitive processes in the regulation of the ATP-ases, ribonucleases and similar systems, as well as with regard to the possible cancerostatic action of vanadates.

As the field of $\mathrm{VO}^{2+} /$ nucleotide interactions has been recently reviewed, ${ }^{57}$ only the most important conclusions are summarized here: in acid media all types of phosphate nucleosides (mono-, di- and tri-phosphates) interact with the cation, but only through the phosphate groups; at high $\mathrm{pH}$ interaction takes place only through the deprotonated $\mathrm{OH}$-groups of D-ribose; at neutral $\mathrm{pH}$ di- and tri-phosphate nucleosides generate $\mathrm{VO}(\text { nucl })_{2}$ complexes at high ligandto-metal ratios; at lower ratios, participation of $\mathrm{N}$ atoms of the nucleic acid bases occurs. The behavior of monophosphate nucleosides is more complex. Important ligand rearrangements take place with increasing $\mathrm{pH}$. Phosphate groups, together with $\mathrm{OH}$-groups of D-ribose, participate in coordination.

Interaction of the $\mathrm{VO}^{2+}$ cation with the nucleic bases ${ }^{58}$ and with nucleosides ${ }^{59}$ has also been investigated.

Even though different solid $\mathrm{VO}^{2+} /$ nucleotide complexes have been reported, ${ }^{60}$ but they have not been well characterized. Our own experience in these systems has shown that the isolation and purification of such complexes is not easy. ${ }^{12}$

Simple and complex phosphates deserve special attention, not only to the presence of vanadium in nucleotides but also due to its participation in a wide range of biological systems and processes. ${ }^{12}$

D-ribose-5-phosphate (Rib-5P) shows a similar solution behavior to the monophosphate nucleosides ${ }^{61}$ and three powdered solid oxovanadium(IV) complexes containing this species were isolated and characterized. ${ }^{62}$ The spectroscopic analysis of the light blue species [VO(Rib$\left.5 \mathrm{P})(\mathrm{OH})\left(\mathrm{H}_{2} \mathrm{O}\right)_{2}\right] \cdot 2 \mathrm{H}_{2} \mathrm{O}$ and $\left[\mathrm{VO}(\mathrm{Rib}-5 \mathrm{P})\left(\mathrm{H}_{2} \mathrm{O}\right)_{3} \mathrm{Cl}\right.$ shows coordination through oxygen atoms of the phosphate group which is bidentate in the first case and monodentate in the second. In contrast, in the green 
$\mathrm{Na}_{6}\left[\mathrm{VO}(\mathrm{Rib}-5 \mathrm{P})_{2}\right] \cdot 6 \mathrm{H}_{2} \mathrm{O}$ complex, coordination takes place through pairs of two adjacent deprotonated $\mathrm{OH}$-groups of the sugar moiety.

Phytic acid and thiamine diphosphates are other biologically interesting phosphates. From the nutritional point of view, phytic acid (mio-inositol hexaphosphate) appears especially interesting because of its important effects on the bioavailability of essential trace metals. ${ }^{63}$ Depending on the $\mathrm{pH}$, the $\mathrm{VO}^{2+}$ cation interacts with phytate forming both soluble and insoluble complexes. ${ }^{64}$

Regarding thiamine diphosphate (cocarboxylase, TDP), a coenzyme that catalyzes the decarboxylation of $\alpha$-ketoacids, we have found that in the $\mathrm{pH}$-range 3-4 a 1:1 complex with $\mathrm{VO}^{2+}$ is formed, and this involves only $O$-phosphate bonds. The participation of the N(1) atom of the pyrimidine ring in bonding has been suggested at higher $\mathrm{pH}^{65} \mathrm{~A}$ solid complex of composition [VO(TDP)Cl].7 $\mathrm{H}_{2} \mathrm{O}$, was precipitated with ethanol from an aqueous solution at $\mathrm{pH}$ 3.5. In this complex, the terminal $\mathrm{PO}_{3}$ group of TDP is bidentate. ${ }^{66}$

Another complex, relevant to a better understanding of the $\mathrm{VO}^{2+} /$ phosphate interactions, is the recently investigated trimer species $\mathrm{Na}_{6}\left[(\mathrm{VO})_{3}\left(\mathrm{P}_{2} \mathrm{O}_{7}\right)_{3}\right] \cdot 7 \mathrm{H}_{2} \mathrm{O} .{ }^{67}$

\section{2. $\mathrm{VO}^{2+}$ complexes of carbohydrates}

As carbohydrates are the most abundant class of compounds in the biosphere, ${ }^{12,68}$ the study of their interaction with relevant vanadium species is of great interest. It is well known that sugars interact with metal ions either as reductants and/or chlelators. ${ }^{12,68}$ Most of them reduce vanadates(V) to oxovanadium(IV) and complex this cation. This field of vanadium biochemistry has also been recently reviewed ${ }^{69}$ and therefore we shall reduce the discussion only to its most relevant aspects.

Due to its strong hydrolytic tendency, the $\mathrm{VO}^{2+}$ cation usually needs the presence of additional donor groups (e.g. carboxylates) in the sugar molecule. Once bonded, it can easily deprotonate the $\mathrm{OH}$-groups and strongly coordinate up to four of them. Oxovanadium(IV) complexes coordinated by pairs of doubly deprotonated sugar moieties usually display a very characteristic, three band, electronic absorption spectrum. ${ }^{69,70}$

Oxovanadium(IV) coordination is favored in basic media and only occurs with sugar molecules provided with pairs of adjacent $\mathrm{OH}$-groups. ${ }^{69,71}$

A great number of $\mathrm{VO}^{2+} /$ monosaccharide complexes have been reported in recent years. Their stoichiometries are summarized in Table 1. All these complexes are greencolored powders and are usually hygroscopic and very soluble in water.

Only five oxovanadium complexes with disaccharides as ligands have been so far reported. These are sucrose, ${ }^{74}$ turanose,${ }^{74}$ maltose ${ }^{73,77}$ and lactose,${ }^{78}$ with the following stoichiometries:

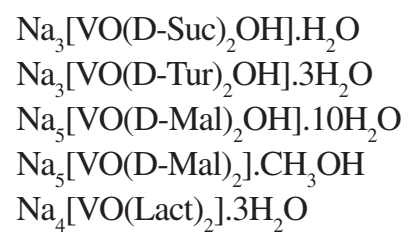

Even though a number of oxovanadium(IV) complexes with some carboxylate derivatives of carbohydrates and sugar phosphates, and with polysaccharides, has been also investigated, most of these compounds remains poorly characterized. ${ }^{69}$

\section{Model Studies Related to Vanadium Detoxification}

Contamination of the environment by vanadium has

Table 1. Composition of the known oxovanadium (IV) monosaccharide complexes

\begin{tabular}{llll}
\hline Complex & Ref. & Complex & Ref. \\
\hline$\left[\mathrm{VO}(\mathrm{D}-\mathrm{Glc})_{2}\right]$ & 72 & $\mathrm{Na}_{4}\left[\mathrm{VO}(\mathrm{L}-\mathrm{Sor})_{2}\right] \cdot 3 \mathrm{H}_{2} \mathrm{O}$ & 76 \\
$\mathrm{Na}_{2}\left[\mathrm{VO}(\mathrm{D}-\mathrm{Glc})_{2}\right] \cdot \mathrm{CH}_{3} \mathrm{OH}$ & 73 & $\mathrm{Na}_{4}\left[\mathrm{VO}(\mathrm{D}-\mathrm{Gal})_{2}\right] \cdot 5 \mathrm{H}_{2} \mathrm{O}$ & 77 \\
$\mathrm{Na}_{3}\left[\mathrm{VO}(\mathrm{D}-\mathrm{Glc})_{2}(\mathrm{OH})\right] \cdot 5 \mathrm{H}_{2} \mathrm{O}$ & 74 & $\mathrm{Na}_{2}\left[\mathrm{VO}(\mathrm{D}-\mathrm{Gal})_{2}(\mathrm{OH}) \mathrm{Cl}\right] \cdot 0 \cdot 5 \mathrm{H}_{2} \mathrm{O}$ & 75 \\
$\mathrm{Na}_{2}\left[\mathrm{VO}(\mathrm{D}-\mathrm{Glc})_{2}(\mathrm{OH}) \mathrm{Cl}\right] \cdot \mathrm{H}_{2} \mathrm{O}$ & 75 & $\mathrm{Na}_{2}\left[\mathrm{VO}(\mathrm{D}-\mathrm{Gal})_{2}\right] \cdot \mathrm{CH} \mathrm{H}_{3} \mathrm{OH}$ & 73 \\
$\mathrm{Na}_{2}\left[\mathrm{VO}(\mathrm{D}-\mathrm{Fru})_{2}\right]$ & 73 & $\mathrm{Na}_{2}\left[\mathrm{VO}(\mathrm{D}-\mathrm{Gal})_{2}\left(\mathrm{H}_{2} \mathrm{O}\right)\right]$ & 76 \\
$\left.\mathrm{Na}_{6}[\mathrm{VO})_{2}(\mathrm{D}-\mathrm{Fru})_{5}\right] \cdot 4 \mathrm{H}_{2} \mathrm{O}$ & 74 & $\mathrm{Na}_{4}\left[\mathrm{VO}(\mathrm{D}-\mathrm{Man})_{2}\right] \cdot 8 \mathrm{H}_{2} \mathrm{O}$ & 73 \\
$\mathrm{Na}_{2}\left[\mathrm{VO}(\mathrm{D}-\mathrm{Fru})_{2}(\mathrm{OH}) \mathrm{Cl}\right] \cdot 5 \mathrm{H}_{2} \mathrm{O}$ & 75 & $\mathrm{Na}_{3}\left[\mathrm{VO}(\mathrm{D}-\mathrm{Man})_{2}\left(\mathrm{OCH}_{3}\right)\right] \cdot 4 \mathrm{CH}_{3} \mathrm{OH}$ & 7 \\
$\mathrm{Na}_{2}\left[\mathrm{VO}(\mathrm{D}-\mathrm{Xyl})_{2}\right] \cdot \mathrm{CH} \mathrm{CH}_{3} \mathrm{OH}$ & 76 & $\mathrm{Na}_{5}\left[\mathrm{VO}(\mathrm{D}-\mathrm{Lyx})_{2}(\mathrm{OH})\right] \cdot 6 \mathrm{H}_{2} \mathrm{O}$ & 76 \\
$\mathrm{Na}_{4}\left[\mathrm{VO}(\mathrm{D}-\mathrm{Xyl})_{2}\right] \cdot 5 \mathrm{H}_{2} \mathrm{O}$ & 77 & $\mathrm{Na}_{4}\left[\mathrm{VO}(\mathrm{D}-\mathrm{Lyx})_{2}\right] \cdot 2 \mathrm{H}_{2} \mathrm{O}$ & 76 \\
$\mathrm{Na}_{2}\left[\mathrm{VO}(\mathrm{D}-\mathrm{Xyl})_{2}(\mathrm{HO}) \mathrm{Cl}\right] \cdot \mathrm{CH}_{3} \mathrm{OH} \cdot 1 \cdot 5 \mathrm{H}_{2} \mathrm{O}$ & 75 & $\mathrm{Na}_{2}\left[\mathrm{VO}(\mathrm{InO})_{2}\right]$ & \\
$\mathrm{Na}_{4}\left[\mathrm{VO}(\mathrm{D}-\mathrm{Ara})_{2}\right] \cdot \mathrm{CH}_{3} \mathrm{OH} \cdot 3 \mathrm{H}_{2} \mathrm{O}$ & 76 & $\mathrm{Na}_{4}\left[\mathrm{VO}(\mathrm{D}-\mathrm{Rib})_{2}\right] \cdot \mathrm{H}_{2} \mathrm{O}$ & 76 \\
$\mathrm{Na}_{4}\left[\mathrm{VO}(\mathrm{D}-\mathrm{Ara})_{2}\right] \cdot 5 \mathrm{H}_{2} \mathrm{O}$ & 77 & $\mathrm{Na}_{3}\left[\mathrm{VO}(\mathrm{D}-\mathrm{Rib})_{2}(\mathrm{OH})\right] \cdot 4 \mathrm{H}_{2} \mathrm{O}$ & \\
$\mathrm{Na}_{4}\left[\mathrm{VO}(\mathrm{L}-\mathrm{Ara})_{2}\right] \cdot 5 \mathrm{H}_{2} \mathrm{O}$ & 77 & $\mathrm{Na}_{2}\left[\mathrm{VO}(\mathrm{D}-\mathrm{Rib})_{2}(\mathrm{OH}) \mathrm{Cl}\right] \cdot \mathrm{CH} \mathrm{H}_{3} \mathrm{OH}$ & \\
\hline
\end{tabular}


dramatically increased in recent years, especially in the most developed countries, due to the increasing use of fossil fuels, which liberate $\mathrm{V}_{2} \mathrm{O}_{5}$ during combustion. ${ }^{79}$ Therefore, the toxicology and detoxification of vanadium constitute an area of increasing development.

The degree of toxicity depends on the route of administration, oxidation and chemical form and it is also to some extent species-dependent. Vanadium compounds, especially $\mathrm{V}_{2} \mathrm{O}_{5}$, are strong irritants of the airways and the eyes. Acute and chronic exposure gives rise to conjunctivitis, rhinitis, reversible irritation of the respiratory tract, and to bronchitis, bronchospasms, and asthma-like diseases in more severe cases. It has shown that it can produce gastrointestinal distress, fatigue, cardiac palpitation, and kidney damage. In humans, acute vanadium toxicity has been observed in vanadium miners, as well as other industrial workers exposed to high concentrations of the element. The classic symptoms of this malady, referred to as "green tongue" syndrome, are a green discoloration of the tongue, accompanied by some of the cited disorders..$^{80,81}$

It has been usually accepted that vanadium toxicity increases with increasing oxidation state, vanadium(V) being the most toxic. ${ }^{80,81}$

Living systems have developed defense mechanisms to deal with the reactive and potentially harmful byproducts that arise from cellular metabolism and to control the effects of exogenous substances that eventually invade the organism (biological detoxification). Drugs have been developed to chelate metal ions in vivo, not only to eliminate excesses of essential metals but also to prevent possible damage caused by nonessential, toxic elements (chemical detoxification).

Some of the systems mentioned in this account are evidently relevant to the toxicity and detoxification of vanadium. Some of the metabolic processes (glutathione-, ascorbate- or cysteine- mediated reduction of vanadates $(\mathrm{V})$; complexation of $\mathrm{VO}^{2+}$ by different biomolecules; accumulation of vanadium in hard tissues) must play an important role in biological vanadium detoxification. ${ }^{81}$

Most of the systems assayed for chemical detoxification contain chelating or reducing/chelating agents. ${ }^{81}$ Animal studies have demonstrated that the best detoxification agent may be L-ascorbic acid. ${ }^{81-83}$ Its action is related to the facility with which it reduces vanadium( $\mathrm{V})$ to $\mathrm{VO}^{2+}$ and to the possibility that the oxocation generated may be complexed by its oxidation products, as discussed above.

Better knowledge of the fundamental metabolic steps and a thorough characterization of new vanadium species with chelating or reducing agents may be useful for the development of more potent and specific detoxification agents for vanadium.

\section{Model Studies Related to Haloperoxidases}

Haloperoxidases are enzymes which catalyze the oxidation of halides $\left(\mathrm{Cl}^{-}, \mathrm{Br}^{-}, \mathrm{I}^{-}\right)$by hydrogen peroxide, resulting in the halogenation of appropriate organic substrates. ${ }^{84}$ The presence of vanadium as an essential component for a haloperoxidase was discovered in the red algae Ascophyllum nodosum in $1984 .{ }^{85}$ Within these vanadium-dependent haloperoxidases, both vanadium bromoperoxidases, isolated mainly from algae, and vanadium chloroperoxidases, found essentially in fungi, have been subsequently identified. ${ }^{9}$

Recently, the crystal structure of a vanadium chloroperoxidase isolated from the fungus Curvularia inaequalis, was reported by Messerschmidt and Wever. ${ }^{86}$ The structural features of the active vanadium center seems to be characteristic of all such systems. ${ }^{9}$ The metal, in the V oxidation state, has a trigonal bipyramidal geometry, ligated by azide (a result of the azide-containing crystallization buffer), three non-protein oxygen atoms, and a histidine $\mathrm{N}$ atom. In the native structure the azide ligand, located in trans position to the histidine $\mathrm{N}$ atom, is apparently replaced by an $\mathrm{OH}$ group..$^{9,86}$

The finding of a specific function of vanadium in haloperoxidases allows new speculations, on its possible functions in higher organisms. Thyroid peroxidase is one of the best known animal haloperoxidases ${ }^{84}$ As mentioned previously, vanadium deprivation increases thyroid weight and also affects the response of thyroid peroxidase activity. ${ }^{5,10}$ Perhaps, vanadium plays some role in the halogenating activity of this enzyme.

A great number of model studies have been performed recently, in an attempt to understand better the structural characteristics of the metal site as well as to elucidate the reaction mechanisms the vanadium-dependent haloperoxidases.

All the information so far accumulated shows that vanadium remains in the $\mathrm{V}$ oxidation state during the entire catalytic cycle and it has also been demonstrated that during the process one peroxide group is bonded to the metal. ${ }^{4,87}$ A variety of mechanistic studies has been performed using different vanadium/peroxide complexes as model systems. ${ }^{4,88-91}$ Some vanadium-based semisynthetic and biomimetic models have also been assayed as catalysts for enantioselective oxidations. ${ }^{92}$

Recently, we have also initiated some model studies related to these natural systems, investigating the kinetics of the bromination of phenol red by the peroxovanadium(V) species generated by acid decomposition of $\left[\mathrm{VO}\left(\mathrm{O}_{2}\right)_{2}\left(\mathrm{NH}_{3}\right)\right]^{-}$and $\left[\mathrm{O}\left\{\mathrm{VO}\left(\mathrm{O}_{2}\right)_{2}\right\}_{2}\right]^{4-93}$

Numerous model studies related to the characteristics 
of both the active vanadium (V) site and the catalytically inactive reduced oxovanadium(IV) site, have been also performed. ${ }^{4,14,94-97}$

One interesting aspect of the structure of the active site is the simultaneous presence of $\mathrm{N}$ - and $\mathrm{O}$-donors and of $\mathrm{V}=\mathrm{O}$ and $\mathrm{V}-\mathrm{OH}$ groups. The ligand 8-hydroxyquinoline, the well-known analytical reagent oxine (HQ), is particularly interesting for model studies related to these systems and to other biologically relevant vanadium centers. It normally stabilizes chelate complexes of the types $\mathrm{MQ}_{2}$ and $\mathrm{MQ}_{3}$, generating $\mathrm{MN}_{2} \mathrm{O}_{2}$ or $\mathrm{MN}_{3} \mathrm{O}_{3}$ and, in certain cases, also $\mathrm{MN}_{2} \mathrm{O}_{3}(\mathrm{OH})$ environments.

In spite of the fact that the simplest oxovanadium(IV) complex of oxine, $\mathrm{VOQ}_{2}$, has been widely investigated, several contradictory reports, mainly derived from its easily oxidability, are found in the literature. ${ }^{12}$ In order to extend these studies, we have synthesized and characterized a series of $\mathrm{VO}^{2+}$ complexes with different derivatives of oxine. Those derived from 5,7-dihalogenated oxine are stable in air but show a very complex solution behavior that includes oxidation phenomena, ligand loss and interactions with solvents. ${ }^{98}$ On the other hand, the presence of halogen atoms on the oxine ring has a negligible effect on the thermal stability of the complexes. ${ }^{99}$

A detailed study of the magnetic behavior of these complexes shows that a ferromagnetic interaction between the $\mathrm{VO}^{2+}$ groups becomes operative at temperatures below $40 \mathrm{~K}$ with an exchange integral $J 2.73 \mathrm{~cm}^{-1}{ }^{100}$ These results constitute the first direct evidence of the formation of $\cdots \mathrm{V}=\mathrm{O} \cdots \mathrm{V}=\mathrm{O} \cdots$ ferromagnetic chains in these and in similar oxovanadium(IV) complexes. ${ }^{12,100}$

Other related complexes that were also investigated in detail are the bis-chelated $\mathrm{VO}^{2+}$ species derived from 8hydroxyquinoline- $\mathrm{N}$-oxide. ${ }^{101}$ and from 7 -iodo-8hydroxyquinoline-5-sulfonic acid (the analytical reagent ferron). ${ }^{102}$

Some vanadium $(\mathrm{V})$ species containing oxine or its derivatives as ligands are much more interesting in relation to the active site of haloperoxidases. The complex hydroxobis(8-hydroxyquinolinato)oxovanadium(V) (Figure 4a) can be considered as an "inorganic analog" of a carboxylic acid. ${ }^{12,103}$ Accordingly, it is possible to prepare salts (Figure 4b), esters (Figure 4c) and dimer anhydrides (Figure $4 \mathrm{~d}$ ). We obtained a great number of complexes of these types and characterized them thoroughly by different physicochemical methods, ${ }^{98,101,102,104,105}$ including detailed electrochemical studies. ${ }^{106,107}$

Another class of model system related to this biological site, in its reduced (inactive) form are the recently reported species $c i s$ - $\left[\mathrm{VO}(\mathrm{OH})(\text { bipy })_{2}\right]^{+}$and $c i s-\left[\mathrm{VO}(\mathrm{OH})(o \text {-phen })_{2}\right]^{+}$ which structural analysis, as the $\mathrm{BF}_{4}^{-}$salts, showed the

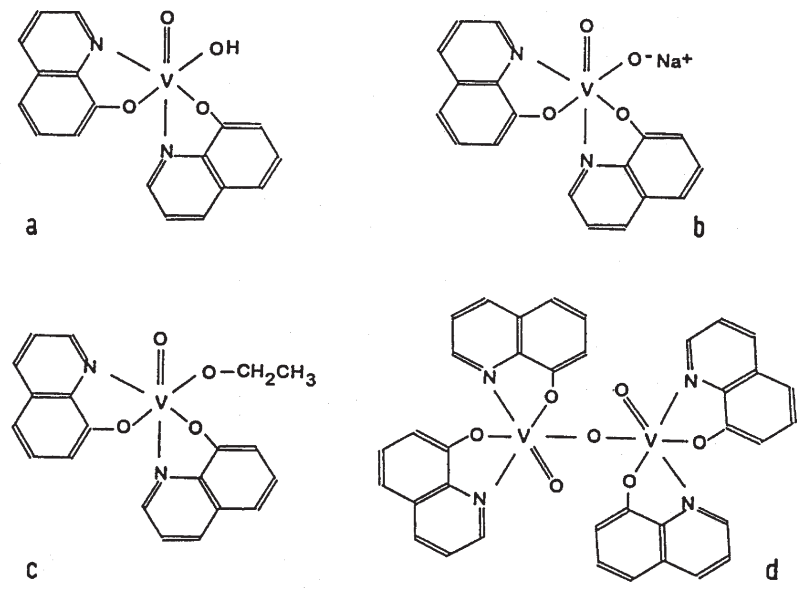

Figure 4. Different compounds in the vanadium (V)/oxine system.

presence of a severely distorted octahedral coordination with the vanadium(IV) above the mean equatorial plane defined by three bipy (o-phen) $\mathrm{N}$-atoms and the $\mathrm{OH}$-group. The oxo group and the remaining $\mathrm{N}$-atom of one of the organic ligands occupy the apical positions. ${ }^{108}$

Also, Schiff-base complexes of vanadium(V) and of oxovanadium(IV) have often been investigated as useful models for this and other biological systems containing the metal. ${ }^{109-115}$

Finally, it is worthy commenting that numerous model compounds developed for a better understanding of the activity and action of vanadium-dependent haloperoxidases and other biological systems containing this element are also reagents in modern organic synthesis. ${ }^{116}$

It is pertinent to emphasize that a number of model compounds investigated in relation to Amavadine, the natural vanadium complex present in the fungus Amanita muscaria (cf. ${ }^{117,118}$ and references therein), also have very interesting catalytic capabilities. ${ }^{119}$

\section{Conclusions and Perspectives}

We hope the above discussion has clearly shown the importance of model studies for a deeper understanding of some fundamental aspects related to the relatively complex biochemistry of vanadium. These studies have revealed valuable information concerning vanadium metabolism, toxicity, detoxification and catalytic activity. They have also extended the coordination chemistry of vanadium, especially that of the vanadium(IV) and vanadium(V) oxocations, as a direct consequence of the use of a variety of new ligand types. Nevertheless, there are a number of very important and interesting problems that remain open.

A better understanding of vanadium metabolism requires new efforts to comprehend its transport in both 
anionic and cationic forms, and for the initial reduction processes of vanadium $(\mathrm{V})$ to $\mathrm{VO}^{2+}$ in the gastrointestinal tract. It would also be interesting to obtain crystalline $\mathrm{VO}^{2+}$ complexes with glutathione and related ligands and to explore further the interaction of this oxocation with serum albumin, transferrin and ferritin. A better chemical characterization of excreted vanadium species also seems very important.

More detailed speciation studies, including the determination of stability constants, are necessary for a wider characterization of the $\mathrm{VO}^{2+} /$ nucleotide systems.

Other efforts should be directed to structural information on oxovanadium(IV) saccharide complexes. It has not yet been possible to obtain single crystals adequate for crystallographic studies, ${ }^{69}$ therefore EXAFS studies, like those recently performed on iron-saccharide complexes, ${ }^{120}$ should be attempted. Studies on the interaction of the $\mathrm{VO}^{2+}$ cation with polysaccharides should also be expanded, as these systems are of particular biological importance.

The possible use of phosphonates and related ligands, as well as the combination of appropriate reducing/ chelating systems for use in vanadium detoxification merits further exploration.

Most of the model systems so far investigated, are also good candidates for theoretical studies, which may be very useful for a better understanding of stability, electronic structures, and reactivity. Some recent examples of this type of work are the molecular modeling of vanadium peroxides $^{121}$ and studies of the electronic structures of Amavadine models. ${ }^{122}$

\section{Acknowledgements}

It is a great pleasure to acknowledge the contributions of the colleagues and collaborators whose names appear in the references. Work from our laboratory reported here was supported by the Consejo Nacional de Investigaciones Científicas y Técnicas de la República Argentina (CONICET), the Comisión de Investigaciones Científicas de la Provincia de Buenos Aires and the Agencia Nacional de Promoción Científica y Tecnológica. The author is a member of the Research Career of CONICET.

\section{References}

1. Chasteen, N.D., ed.; Vanadium in Biological Systems, Kluwer: Dordrecht, 1995.

2. Sigel, H.; Sigel, A., eds.; Metal Ions in Biological Systems, vol.31: Vanadium and its Role in Life, Marcel Dekker: New York, 1995.
3. Rehder, D.; Angew. Chem. Int. Ed. Engl. 1991, 30, 148.

4. Slebodnick, C.; Hamstra, B. J.; Pecoraro, V. L.; Struct. Bonding 1997, 89, 51.

5. Baran, E. J.; An. Soc. Científ. Argent. 1998, 228, 61.

6. Eady, R. R.; Leight, G. F.; J. Chem. Soc., Dalton Trans. 1994, 2739.

7. Eady, R. R.; Chem. Rev. 1996, 96, 3013.

8. Wever, R.; Kustin, K.; Adv. Inorg. Chem. 1990, 35, 81.

9. Butler, A.; Baldwin, A. H.; Struct. Bonding 1997, 89, 109.

10. Nielsen, F. H.; FASEB J. 1991, 5, 2661.

11. Rehder, D.; Biometals 1992, 5, 3.

12. Baran, E. J.; J. Inorg. Biochem. 2000, 80, 1.

13. Butler, A.; Carrano, C.J.; Coord. Chem. Rev. 1991, 109, 61.

14. Rehder, D.; Coord. Chem. Rev. 1999, 182, 297.

15. Chasteen, N. D.; Lord, M. E.; Thompson H. J. In Frontiers in Bioinorganic Chemistry; Xavier, A. V., ed., Verlag Chemie: Weinheim, 1986, pp.133-141.

16. Baran, E. J.; Bol. Soc. Chil. Quim. 1997, 42, 247.

17. Rabenstein, D.L. In Glutathione; Dolphin, D.; Avramovic, O.; Poulson, R., eds.; J. Wiley: New York, 1989, part A, pp.147186.

18. Macara, I. G.; Kustin, K.; Cantley,jr., L. C.; Biochim. Biophys. Acta 1980, 629, 95.

19. Delfini, M.; Gaggeli, E.; Lepri, A.; Valensin, G.; Inorg. Chim. Acta 1985, 107, 87.

20. Ferrer, E.G.; Williams, P. A. M.; Baran, E.J.; Biol. Trace Elem. Res. 1991, 30, 175.

21. Armas, M. T.; Mederos, A.; Gili, P.; Domínguez, S.; HernándezMolina, R.; Lorenzo, P.; Baran, E. J.; Araujo, M. L.; Brito, F.; Polyhedron 2001, 20, 799.

22. Costa Pessoa, J.; Tomaz, I.; Kiss, T; Kiss, E.; Buglyó, P.; J. Biol. Inorg. Chem. 2002, 7, 225.

23. Dessi, A.; Micera, G.; Sanna, D.; J. Inorg. Biochem. 1993, 52, 275.

24. Tasiopoulos, A. J.; Troganis, A. N.; Evangelou, A.; Raptopoulou, C. P.; Terzis, A.; Deligiannakis, Y.; Kabanos, T. A.; Chem. Eur. J. 1999, 5, 910.

25. Ferrer, E. G.; Williams, P. A. M.; Baran, E. J.; J. Inorg. Biochem. 1993, 50, 253.

26. Costa Pessoa, J.; Tomaz, I.; Kiss, T.; Buglyó, P.; J. Inorg. Biochem. 2001, 84, 259.

27. Sakurai, H.; Shimomura, K.; Ishizu, K.; Inorg. Chim. Acta 1981, 55, L67.

28. Sakurai, H.; Hamada, Y.; Shimomura, S.; Yamashita, S.; Ishizu, K.; Inorg. Chim. Acta 1980, 46, L119.

29. Ferrer, E. G.; Baran, E. J.; An. Asoc. Quim. Argent. 1992, 80, 429.

30. Ferrer, E. G.; Williams, P. A. M.; Baran, E. J.; J. Trace Elem. Med. Biol. 1998, 12, 56.

31. Baran, E.J.; Ferrer, E.G.; Williams, P. A. M.; J. Inorg. Biochem. 1995, 59, 600 . 
32. Ferrer, E. G.; Williams, P. A. M.; Baran, E. J.; Z. Naturforsch. 1998, $53 b, 256$.

33. Ferrer, E. G.; Baran, E. J.; Biol. Trace Elem. Res. 2001, 83, 111.

34. Chasteen, N. D. In Metal Ions in Biological Systems; Sigel, H.; Sigel, A., eds.; Marcel Dekker: New York, 1995, vol.31, pp.231-247.

35. Cantley, L. C.; Resh, M.; Guigotti, G.; Nature 1978, 272, 552.

36. Harris, W. R.; Carrano, C. J.; J. Inorg. Biochem. 1984, 22, 201.

37. Smith, C. A.; Ainscough, E. W.; Brodie, A. M.; J. Chem. Soc., Dalton Trans. 1995, 1121.

38. Neves, A.; Ceccato, A. S.; Erasmus-Buhr, C.; Gehring, S.; Haase, W.; Paulus, H.; Nascimento, O. R.; Batista, A. A.; J. Chem. Soc. Chem.Comm. 1993, 23, 1782.

39. Neves, A.; de Moraes Romanowski, S. M.; Bortoluzzi, A. J.; Mangrich, A. S.; Inorg. Chim. Acta 2001, 313, 137.

40. Chasteen, D. N.; Francavilla, J.; J. Phys. Chem. 1976, 80, 867.

41. Purcell, M.; Neault, J. F.; Malonga, H.; Arakawa, H.; TajmirRiahi, H. A.; Can. J. Chem. 2001, 79, 1415.

42. Chasteen, N. D.; Grady, J. K.; Holloway, C. E.; Inorg. Chem. 1986, 25, 2754.

43. Heinemann, G.; Fichtl, B.; Mentler, M.; Vogt, W.; J. Inorg. Biochem. 2002, 90, 38 .

44. Etcheverry, S. B.; Apella, M. C.; Baran, E. J.; J. Inorg. Biochem. 1984, 20, 269.

45. Oniki, T.; Doi, Y.; Calc. Tiss. Internat. 1983, 35, 538.

46. Narda, G. E.; Vega, E. D.; Pedregosa, J. C.; Etcheverry, S. B.; Baran, E. J.; Z. Naturforsch. 1992, 47b, 395.

47. Vega, E. D.; Pedregosa, J. C.; Narda, G. E.; J. Phys. Chem. Solids 1999, 60, 759.

48. Baran, E.J.; Acta Farm. Bonaerense 1997, 16, 43.

49. Dikanov, S. A.; Liboirn, B. D.; Thompson, K. H.; Vera, E.; Yuen, V. G.; McNeill, J. H.; Orvig, C.; J. Am. Chem. Soc. 1999, 121, 11004.

50. Ferrari, R. P. Inorg. Chim. Acta 1990, 176, 83.

51. Etcheverry, S. B.; Williams, P. A. M.; Baran, E. J.; Biol. Trace Elem. Res. 1994, 42, 43.

52. Etcheverry, S. B.; Williams, P. A. M.; Baran, E. J.; Biol. Trace Elem. Res. 1996, 51, 169.

53. Sabbioni, E.; Marafante, E.; Bioinorg. Chem. 1978, 9, 389.

54. Kramer, H. J.; Backer, A.; Meyer-Lehnert, H.; Am. J. Hypertens. 1998, 11, 1208.

55. Kramer, H. J.; Krampitz, G.; Backer, A.; Meyer-Lehnert, H.; Clin. Exper. Hypertens. 1998, 20, 557.

56. De Cremer, K.; Cornelis, R.; Strickmans, K.; Dams, R.; Lameire, N.; Vanholder, R.; J. Inorg. Biochem. 2002, 90, 71.

57. Baran, E.J. In Metal Ions in Biological Systems; Sigel, H.; Sigel, A., eds.; Marcel Dekker: New York, 1995, vol.31, pp.129-146.

58. Williams, P. A. M.; Etcheverry, S. B.; Baran, E. J.; Z.Naturforsch. 1993, 48b, 1845 .
59. Williams, P. A. M.; Etcheverry, S. B.; Baran, E. J.; An. Asoc. Quim. Argent. 1994, 82, 13.

60. Katsaros, N.; Transit. Met. Chem. 1982, 7, 62.

61. Williams, P. A. M.; Baran, E. J. ;J. Inorg. Biochem. 1993, 50, 101.

62. Williams, P. A. M.; Etcheverry, S. B.; Baran, E. J.; J. Inorg. Biochem. 1997, 65, 133.

63. Cosgrove, D. J.; Inositol Phosphates: Their Chemistry, Biochemistry and Physiology; Elsevier: New York, 1980.

64. Williams, P. A. M.; Baran, E. J.; Biol. Trace Elem. Res. 1993, $36,43$.

65. Williams, P. A. M.; Baran, E. J.; J. Inorg. Biochem. 1990, 38, 101.

66. Ferrer, E. G.; Etcheverry, S. B.; Baran, E. J.; An. Asoc. Quim. Argent. 1998, 86, 146.

67. Muglia, C. I.; Ferrer, E. G.; Baran, E. J.; J. Thermal Anal. Calorim. 2001, 65, 177.

68. Whitfield, D. M.; Stojkovski, S,; Sarkar, B.; Coord. Chem. Rev. 1993, 122, 171.

69. Baran, E. J.; J. Carbohydr. Chem. 2001, 20, 769.

70. Baran, E. J.; J. Coord. Chem. 2001, 54, 215.

71. Branca, M.; Micera, A.; Dessi, A.; Sanna, D.; J. Inorg. Biochem. 1992, 45, 169

72. Rao, C. P.; Kaiwar, S. P.; Inorg. Chim. Acta 1991, 186, L11.

73. Sreedhara, A.; Raghavan, M. S. S.; Rao, C. P.; Carbohyd. Res. 1994, 264, 227.

74. Etcheverry, S. B.; Williams, P. A. M.; Baran, E. J.; Carbohyd. Res. 1997, 302, 131.

75. Bandwar, R. P,.; Rao, C. P.; J. Inorg. Biochem. 1997, 68, 1.

76. Sreedhara, A.; Rao, C. P.; Rao, B. J.; Carbohyd. Res. 1996, $289,39$.

77. Williams, P. A. M.; Etcheverry, S. B.; Baran, E. J.; Carbohyd. Res. 2000, 329, 41.

78. Etcheverry, S. B.; Barrio, D. A.; Williams, P. A. M.; Baran, E. J.; Biol. Trace Elem. Res. 2001, 84, 227.

79. Mamane, Y.; Pirrone, N. In Vanadium in the Environment; Nriagu, J. O., ed.; J. Wiley: New York, 1998, vol.1, pp. 37-71.

80. Faulkner-Hudson, T.G.; Vanadium: Toxicology and Biological Significance ; Elsevier: Amsterdam, 1964.

81. Baran, E. J. In Vanadium in the Environment; Nriagu, J. O., ed.; J. Wiley: New York, 1998, vol.2, pp. 317-345.

82. Jones, M. M.; Basinger, M. A.; J. Toxicol. Enviorn. Health 1983, 12, 749

83. Domingo, J. L.; Llobet, J. M.; Corbella, J.; Toxicol. Lett. 1985, 26, 95.

84. Baran, E. J.; Química Bioinorgánica; McGraw-Hill Interamericana de España: Madrid, 1995.

85. Vilter, H.; Phytochemistry 1984, 23, 1387.

86. Messerschmidt, A.; Wever, R.; Proc. Natl. Acad. Sci. USA 1996, 93, 392.

87. Butler, A.; Coord. Chem. Rev. 1999, 187, 17. 
88. Butler, A.; Clague, M. J.; Meister, G. E.; Chem. Rev. 1994, 94, 625 .

89. Butler, A.; Clague, M. J. In Mechanistic Bioinorganic Chemistry; Thorp, H. H.;Pecoraro, V. L., eds.; Am. Chem. Soc.: Washington, 1995, pp. 329-349.

90. Guevara-García, J. A.; Barba-Behrens, N.; Contreras, R.; Mendoza-Díaz, G. In Vanadium Compounds: Chemistry, Biochemistry, and Therapeutic Applications; Tracey, A. S.; Crans, D. C., eds., Am. Chem. Soc.: Washington, 1998, pp. 126-135.

91. Pecoraro, V. L.; Slebodnick, Hamstra, B. In Vanadium Compounds: Chemistry, Biochemistry, and Therapeutic Applications; Tracey, A. S.; Crans, D. C., eds., Am. Chem. Soc.: Washington, 1998, pp.157-167.

92. van de Velde, F.; Arends, I. W. C. E.; Sheldon, R. A.; J. Inorg. Biochem. 2000, 80, 81.

93. Tótaro, R. M.; Williams, P. A. M.; Apella, M. C.; Blesa, M. A.; Baran, E. J.; J. Chem. Soc. Dalton Trans. 2000, 4403.

94. Plass, W.; Z. Anorg. Allg. Chem. 1994, 620, 1635.

95. Plass, W.: Inorg. Chim. Acta 1996, 244, 221.

96. Hamstra, B. J.; Colpas, G. J.; Pecoraro, V. L.; Inorg. Chem. 1998, 37, 949 .

97. Kimblin, C.; Bu, X.; Butler, A.: Inorg. Chem. 2002, 41, 161.

98. González-Baró, A. C.; Baran, E. J.; Monatsh. Chem. 1997, $128,323$.

99. Ferrer, E. G.; González-Baró, A. C.; Baran, E. J.; J. Thermal Anal. Calorim. 1999, 57, 595.

100. Sáez-Puche, R.; Romero, J.; González-Baró, A. C.; Baran, E. J.; Chem. Phys. Lett. 1998, 282, 273.

101. González-Baró, A. C.; Baran, E. J.; J. Coord. Chem. 1998, 43, 335.

102. González-Baró, A. C.; Baran, E. J.; J. Braz. Chem. Soc. 2001, $12,208$.

103. Giacomelli, A.; Floriani, C.; de Souza Duarte, A. O.; ChiesiVilla, A.; Guastini, C.; Inorg. Chem. 1982, 21, 3310.

104. Jubert, A. H.; González-Baró, A. C.; Pis Diez, R.; Baran, E. J.; J. Raman Spectr. 1992, 23, 273.

105. González-Baró, A. C.; Piro, O. E.; Parajón-Costa, B. S.; Baran, E. J.; Castellano, E. E.; Monatsh. Chem. 1998, 129, 31
106. Parajón-Costa, B. S.; González-Baró, A. C.; Baran, E. J.; J. Coord Chem. 1999, 47, 417.

107. Parajón-Costa, B. S.; González-Baró, A. C.; Baran, E. J.; J. Coord.Chem. 1999, 49, 17

108. Tolis, E. J.; Manos, M. J.; Tasiopoulos, A. J.; Raptopoulou, C. P.; Terzis, A.; Sigalas, M. P.; Deligiannakis, Y.; Kabanos, T. A.; Angew. Chem. Int. Ed. Engl. 2002, 41, 2797.

109. Cornman, C. R.; Kampf, J.; Pecoraro, V. L.; Inorg. Chem. 1992, 31, 1981

110. Cornman, C. R.; Kampf, J.; Lah, H. S.; Pecoraro, V. L.; Inorg. Chem. 1992, 31, 2035.

111. Costa Pessoa, J.; Silva, A. L.; Viera, A. L. Vilas-Boas, L. F.; O'Brien, P.; Thornton, P.; J. Chem. Soc. Dalton Trans. 1992, 1745 .

112. Vergopoulos, V.; Priebsch, W.; Fritsche, M.; Rehder, D.; Inorg. Chem. 1993, 32, 1844.

113. Cavaco, J.; Costa Pessoa, J.; Costa, D.; Duarte, M. T.; Gillard, R.D.; Matias, P.; J. Chem. Soc. Dalton Trans. 1994, 149.

114. Plass, W.; Coord. Chem. Rev. 2003, 237, 205.

115. Tsuchida, E.; Oyaizu, K.; Coord. Chem. Rev. 2003, 237, 213.

116. Hirao, T.; Chem. Rev. 1997, 97, 2707.

117. Bayer, E. In Metal Ions in Biological Systems; Sigel, H.; Sigel, A., eds.; M. Dekker: New York, 1995, Vol.31, pp.407-421.

118. Garner, C. D.; Armstrong, E. M.; Berry, R. E.; Beddoes, R. L.; Collison, D.; Cooney, J. J. A.; Ertok, S. N.; Helliwell, M.; J. Inorg. Biochem. 2000, 80, 17.

119. Reis, P. M.; Silva, J. A. L.; Fraústo da Silva, J. R.; Pombeiro, A. J. L.; J.Chem. Soc. Chem. Comm. 2000, 1845.

120. Rao, C. P.; Geetha, K.; Raghavan, M. S. S.; Sreedhara, A.; Tokunaga, K.; Yamaguchi, T.; Jadhav, V.; Ganesh, K. N.; Krishnamoorthy, T.; Ramaiah, K. V. A.; Bhattacharyya, R. K.; Inorg. Chim. Acta 2000, 297, 373.

121. Cundari, T. R.; Sisterhen, L. L.; Stylianopoulos, C.; Inorg. Chem. 1997, 36, 4029.

122. Armstrong, E. M.; Collison, D.; Deeth, R. J.; Garner, C. D.; J. Chem. Soc. Dalton Trans. 1995, 191.

Received: November 11, 2002 Published on the web: October 9, 2003 